\title{
Malaria entomological risk factors in relation to land cover in the Lower Caura River Basin, Venezuela
}

\author{
Yasmin Rubio-Palis ${ }^{1,2}{ }^{+}$, Mariapia Bevilacqua ${ }^{3}$, Domingo Alberto Medina ${ }^{3}$, Jorge Ernesto Moreno ${ }^{4}$, \\ Lya Cárdenas ${ }^{3}$, Víctor Sánchez ${ }^{4}$, Yarys Estrada ${ }^{4}$, William Anaya ${ }^{1}$, Ángela Martínez ${ }^{5}$
}

'Dirección de Salud Ambiental, Ministerio del Poder Popular para la Salud, Maracay, Venezuela ${ }^{2}$ Centro de Investigaciones Biomedicas, Facultad de Ciencias de la Salud, Universidad de Carabobo, Maracay, Venezuela ${ }^{3}$ Asociación Venezolana para la Conservación de Áreas Naturales, Caracas, Venezuela ${ }^{4}$ Instituto de Altos Estudios de Salud Pública Dr Arnoldo Gabaldon, Centro de Investigaciones de Campo

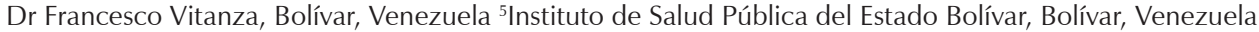

To explore the effects of deforestation and resulting differences in vegetation and land cover on entomological parameters, such as anopheline species composition, abundance, biting rate, parity and entomological inoculation rate (EIR), three villages were selected in the Lower Caura River Basin, state of Bolivar, Venezuela. All-night mosquito collections were conducted between March 2008-January 2009 using CDC light traps and Mosquito Magnet ${ }^{\mathbb{B}}$ Liberty Plus. Human landing catches were performed between 06:00 pm-10:00 pm, when anophelines were most active. Four types of vegetation were identified. The Annual Parasite Index was not correlated with the type of vegetation. The least abundantly forested village had the highest anopheline abundance, biting rate and species diversity. Anopheles darlingi and Anopheles nuneztovari were the most abundant species and were collected in all three villages. Both species showed unique biting cycles. The more abundantly forested village of El Palmar reported the highest EIR. The results confirmed previous observations that the impacts of deforestation and resulting changes in vegetation cover on malaria transmission are complex and vary locally.

Key words: deforestation - Anopheles darlingi - entomological inoculation rate

The state of Bolívar in Venezuela is the state where most malaria cases are reported, accounting for $85.8 \%$ of the total number of malaria cases reported in the country (MPPS 2011). The Caura River Basin is a vast territory of 4.5 million hectares and malaria is endemic among its indigenous populations. The basin is in the municipality of Sucre, which accounts for only $8.2 \%$ of the total cases reported for Bolívar. However, the Annual Parasite Index (API) for the population of the municipality of Sucre is 103.0 per 1,000 persons and stands second among the 10 municipalities with the highest malaria transmission rates in Venezuela (MPPS 2011). Until now there has been little information available regarding vector species and their bionomics and there is not sufficient relevant information for the prevention and control of malaria.

The estimation of malaria entomological risk factors is important for planning, implementing and evaluating the effectiveness of vector control programs. Entomological factors, such as species composition, vector abundance, human biting rate, parity, sporozoite rate and entomological inoculation rate (EIR), are all influenced by local and seasonal environmental factors. Factors such as climate and the physical and chemical conditions in mosquito habitats determine the distribution and ecology of a given species (WHO 1975).

Financial support: IDRC Canada) (103696-006), European Union Delegation in Venezuela (DCI-NSAPVD/2008/166-318)

+ Corresponding author: rubiopalis@gmail.com

Received 5 October 2012

Accepted 24 January 2013
Several studies have shown that deforestation and changes in land use affect disease vectors and alter disease patterns (Walsh et al. 1993, Molyneaux 2003, Patz et al. 2005). Mosquitoes are very sensitive to environmental changes due to deforestation, which results in small changes in environmental conditions, such as in the temperature, humidity and availability of suitable larval habitats that might affect their species distribution, survival and density (Martens 1998, Molyneaux 1998); these changes will in turn differentially influence the incidence and prevalence of malaria (Walsh et al. 1993). Afrane et al. $(2005,2008)$ showed that deforestation in western Kenya resulted in an increase in temperature that led to a decrease in the duration of sporogony of Plasmodium falciparum and, together with increases in mosquito density, biting frequency and survivorship, contributed to a $77.7 \%$ increase in the vectorial capacity of Anopheles gambiae Giles sensu stricto.

Studies conducted in the northern Peruvian Amazon and western Brazilian Amazon have shown that the degree of deforestation and ecological alterations influence the risk of contracting malaria (Vittor et al. 2006, Olson et al. 2010). Anopheles darlingi human biting rate was higher in areas with more deforestation and development associated with road construction in Peru (Vittor et al. 2006), while a $4.3 \%$ increase in deforestation resulted in a $48 \%$ increase in malaria incidence in Brazil (Olson et al. 2010). Additionally, Pattanayak and Yasuoka (2008) found that deforestation was correlated with a greater incidence of malaria when modelling malaria prevalence and forest cover in 490 Brazilian micro-regions.

Yasuoka and Levins (2007) analysed 60 studies related to changes in anopheline ecology and malaria inci- 
dence due to deforestation and agricultural development and found that the mechanisms linking these factors are extremely complex and results diverged significantly depending on local anopheline species and ecological conditions.

To test the hypothesis that different types of vegetation and land cover due to deforestation have different impacts on entomological malaria risk factors, three villages representing the central Guiana Shield region were selected in the Lower Caura River Basin, Bolívar, Venezuela.

\section{MATERIALS AND METHODS}

Study site - A longitudinal study was conducted in three riverine villages located in Bolívar (Fig. 1). Surapire and Jabillal are located in the municipality of Sucre and El Palmar is located in the municipality of Cedeño. Surapire (Kadajiyuña) $\left(06^{\circ} 28^{\prime} \mathrm{N} 064^{\circ} 45^{\prime} \mathrm{W}\right)$, the most southern village, is located $146.4 \mathrm{~km}$ from Maripa, the capital of the municipality, and inhabited by Amerindians of the Ye'kwana ethnic group (Carib-speaking), with a population of 72 inhabitants and 12 houses; El Palmar $\left(06^{\circ} 34^{\prime} 53.35^{\prime \prime} 064^{\circ} 49^{\prime} 35.25^{\prime \prime} \mathrm{W}\right)$, which is located $34 \mathrm{~km}$ north and downriver of Surapire, is inhabited by the Sane$m a$ ethnic group (Yanonami sub-group), with 104 inhabitants and 15 houses; Jabillal ( $\left.07^{\circ} 03^{\prime} 43^{\prime \prime} \mathrm{N} 64^{\circ} 58^{\prime} 37^{\prime \prime} \mathrm{W}\right)$, which is located $49.3 \mathrm{~km}$ downriver of El Palmar, is inhabited by a criollos population of mixed heritage (creole group), with 101 inhabitants and 37 houses distributed along a dirt road. Malaria is mainly attributable to Plasmodium vivax, with an overall API of 277.98 per 1,000 individuals. The area has been previously described in detail (Bevilacqua et al. 2009, Medina et al. 2011). The annual rainfall fluctuates between 1,976-2,620 $\mathrm{mm}$ and is marked by the dry season between January-March (less than $60 \mathrm{~mm}$ of rainfall) (Guevara 2005) and wet season from April-December, with peak rainfall during July and August (Vargas \& Rangel 1996).

Vegetation types and land cover - For this study, a Landsat $7 \mathrm{ETM}+30$ meters $\times 30$ meters resolution image (path 2, row 55, 11 March 2005-L71002055_05520050311)

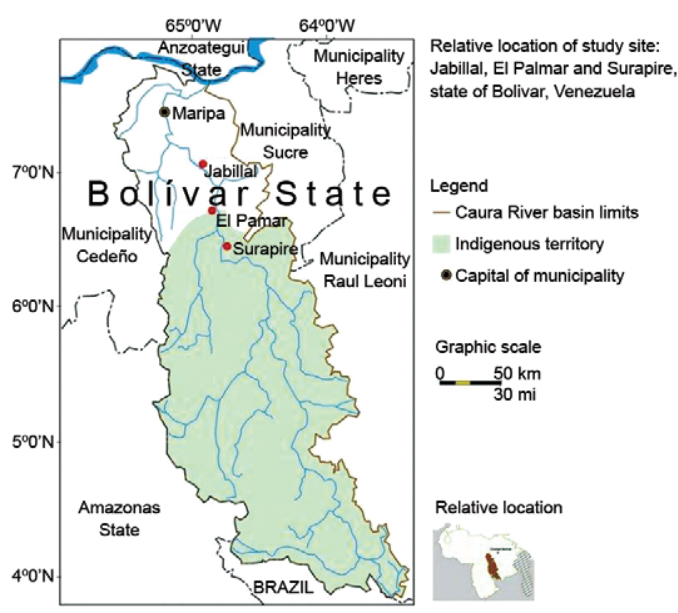

Fig. 1: relative location of study site, Lower Caura River Basin, municipalities of Sucre and Cedeño, state of Bolívar, Venezuela. covering the three communities of interest was interpreted. This image was taken closest to the time of this study and had the least amount of cloud cover, permitting the vegetation cover around the communities to be analysed. Unsupervised classification was performed using the module ISODATA in IDRISI TAIGA v. 16.04. (clarklabs. org). The module uses a data analysis algorithm to partition an n-dimensional image into a number of clusters based on a specified value. Centres of clusters are placed given certain parameters and pixels are assigned according to their shortest distance to the centres. The user establishes a threshold parameter and clusters of pixels are split or merged depending on if one or more standard deviations are greater or less than the user-defined threshold. Cluster centres are updated through multiple iterations until the threshold is reached (Eastman 2009). In combination with the unsupervised classification, the module Segmentation in IDRISI TAIGA was utilised for supervised classification. This process involves defining homogenous pixels into similar spectral image segments determined by a threshold. Segments are then used to create training sites and spectral signatures and the image is then classified using a majority rule algorithm (Eastman 2009). The final vegetation and land cover classes resulting from these procedures were validated in the field.

The surface area of each vegetation type was determined in the classified image within a circular buffer with a $5 \mathrm{~km}$ radius centred on each community. Water body coverage was also estimated for potential larval habitats. The selected buffer size was based on the estimated maximum flight distance of anopheline mosquitoes.

The value in hectares and percentage of each unit of vegetation and land cover around each community was used as an indirect measure of deforestation. Given our understanding of the patterns of land use and land use changes in the area, we assumed that the mosaic of vegetation observed in the satellite image was the product of the dynamics of deforestation for agriculture (deforestation for opening new agricultural areas, soil preparation, crop cultivation and vegetation in succession stages) and the dynamics of agricultural areas abandoned for fallow (vegetation in early and late succession stages).

Malaria prevalence - The number of cases reported monthly by the health post [Institute of Public Health (ISP) 2008] was recorded and the API was estimated based on the population census performed by the research team during 2008.

Mosquito catches - Between March 2008-January 2009 , mosquitoes were collected every two months from sunset to sunrise over three consecutive nights in each village using CDC light traps (3) and Mosquito Magnets (2). Three CDC light traps were run simultaneously in three selected houses where dwellers slept protected by bednets. Meanwhile, two Mosquito Magnet Liberty Plus $^{\mathrm{TM}}+$ octenol (MMLP) traps were placed outdoors following the manufacturer's recommendations (mosquitomagnet.com), i.e., over $3 \mathrm{~m}$ away from walls, buildings, fences and bushes. The traps were placed in approximately the same place throughout the study. In Jabillal, human landing catches (HLC) were also performed by 
two members of the research team. Collections were conducted when biting anophelines are more active, i.e., from 05:30 pm-09:30 pm (Rubio-Palis et al. 2010), three nights per month every two months between June 2008January 2009. The following morning, all mosquitoes collected with each method were killed, identified and kept dry over silica gel for future ELISA tests. Adult females were identified using the keys by Cova Garcia and Sutil (1977), Faran and Linthicum (1981), Consoli and Lourenço-de-Oliveira (1994) and Rubio-Palis (2000).

Species diversity - The number of mosquitoes collected nightly by all three methods and identified in each village was analysed to compare the species diversity or species richness between the three villages. A non-parametric analysis of similarities (ANOSIM) test (Clarke 1993) was conducted using PAST software (Hammer et al. 2001). Significant differences between the species diversities for the villages were determined by Bray-Curtis distances and the similarity percentage (SIMPER) method (Clarke 1993) was used to assess which species were primarily responsible for the observed differences between villages.

Biting activity and parity - To determine anopheline biting activity, MMLP nets were changed every hour and samples were kept moist inside polyporous boxes. The following morning, mosquitoes were killed, identified and dissected to determine parity by the Detinova technique, i.e., stretched or coiled tracheolar skeins (Detinova 1962). Heads and thoraces were kept dry over silica gel until an ELISA for identification of Plasmodium circum-sporozoite (CS) protein.

Human-biting rate - The mean number of mosquitoes caught per day per person was estimated for the two most common species caught in each village, considering all catching methods; an HLC is equivalent to three CDC light trap catches (Moreno et al. 2002) and the equivalence for the MMLP trap was estimated as $31 \%$ for An. darlingi and $63 \%$ for Anopheles nuneztovari Gabaldon (Rubio-Palis et al. 2012). The software SPSS v. 15.0.1 (2006) was used for data analysis.

ELISA procedure - Mosquitoes of the same species from the same village, date and trapping method were combined in pools of up to 10 mosquitoes. Only heads and thoraces of pooled mosquitoes were ground and tested by ELISA for the CS proteins of $P$. falciparum and $P$. vivax (polymorphs 210 and 247) following standard protocols by Wirtz et al. $(1987,1992)$.

Sporozoite rate and EIR - The number of CS-positive Plasmodium pools was equivalent to the number of CSpositive mosquitoes (the probability of detecting more than one infected mosquito per pool was less than $1 \%$ ); thus, the sporozoite rate was estimated as the percentage of CS-positive mosquitoes divided by the total number of mosquitoes assayed per village and the number caught overall. The annual EIR was estimated as the sporozoite rate multiplied by the human-biting rate, i.e., the mean number of female anopheline mosquitoes caught per night multiplied by 365 days.
Ethics - HLC were conducted by members of the research team who are personnel of the Ministry of Health; this is the current method of catching mosquitoes for malaria surveillance. No additional ethical clearance was necessary.

\section{RESULTS}

Vegetation types and land cover - Vegetation analysis for the Caura and Erebato basins (M Bevilacqua et al., unpublished observations) identified four types of vegetation within a radius of $5 \mathrm{~km}$ around the villages. These types were as follows: forest, vegetation without apparent human intervention, a continuous canopy ranging from intermediate to dense coverage $(>70 \%)$ and with a mean tree altitude of $18-30 \mathrm{~m}$; late secondary vegetation, abandoned agricultural area in late succession stage ( $>5$ years) with trees as the primary life forms and forest as the predominant formation at different stages, with coverage of less than $50 \%$, altitude over $5 \mathrm{~m}$, a stratification profile with two-three strata and some wooden emerging elements; early secondary vegetation, abandoned agricultural area characterised by early succession $(<5$ years) in which the dominant life forms are grasses, bushes and small trees with altitudes between 3-5 m, medium to scanty coverage and a lack of clear vertical stratification; bare soil-subsistence scale agriculture (сописо), rock, bare soil or very little vegetation coverage and vegetation associated with subsistence agriculture (annual crops, such as cassava, plantains and yam). Table I shows the area in hectares and percentage of coverage for each vegetation type, as well as water bodies (potential larval habitats), which include lagoons, rivers, swamps and streams. Surapire and El Palmar had similar forest coverage ( 89.60 and $91.97 \%$, respectively), while Jabillal $(67.8 \%)$ had significantly less forest coverage (Pearson correlation, $\mathrm{p}=0.049$ ), but higher coverage $(22.62 \%)$ by secondary vegetation and subsistence agriculture. Intervening forest in Surapire and El Palmar resulting in late and early secondary vegetation represented less than $2 \%$ of the land cover around these villages.

API - During the study period, 77 P. vivax cases were reported: 32 cases in Jabillal (API $=316.83$ per population of 1,000), 35 cases in El Palmar (API $=336.54$ per population of 1,000) and 10 cases in Surapire (API $=138.89$ per population of 1,000) (Table I). An ANOVA of arcsinetransformed data for different types of land cover and API (Kruskal-Wallis test) were not significant $(\mathrm{p}=0.160)$.

Anopheles species abundance and diversity - A total of 2,963 anophelines were collected by all trapping methods, accounting for 11 species, including species belonging to different species complexes that has yet to be identified by molecular methods (Table II). Mosquito abundance was significantly higher (chi-square $=$ $10.49, \mathrm{p}=0.0053$ ) in Jabillal compared with the other two villages. An. darlingi and An. nuneztovari sensu lato were collected in the three selected villages and were the most abundant species, representing $76.2 \%$ of the total mosquitoes identified. Anopheles albitarsis s.l. was collected only in Jabillal. A Pearson correlation analysis between abundance and API was not significant (rho 
TABLE I

Annual parasite index (API) (per 1,000 population) and surface area of land cover by body waters and types of vegetation in a radius of $5 \mathrm{~km}$ around the three study villages, state of Bolívar, Venezuela

\begin{tabular}{lcccccc}
\hline Village & API & $\begin{array}{c}\text { Water } \\
\text { ha (\%) }\end{array}$ & $\begin{array}{c}\text { Forest }^{b} \\
\text { ha (\%) }\end{array}$ & $\begin{array}{c}\text { Late secondary } \\
\text { vegetation } \\
\text { ha (\%) }\end{array}$ & $\begin{array}{c}\text { Early secondary } \\
\text { vegetation } \\
\text { ha (\%) }\end{array}$ & $\begin{array}{c}\text { Bare soil- } \\
\text { subsistence agriculture } \\
\text { ha (\%) }\end{array}$ \\
\hline Jabillal & 316.83 & $749.27(9.58)$ & $5,300.70(67.80)$ & $1,089.01(13.93)$ & $600.37(7.68)$ & $79.17(1.01)$ \\
Surapire & 138.89 & $684.75(8.68)$ & $7,066.50(89.60)$ & $89.63(1.14)$ & $37.38(0.47)$ & $9.81(0.12)$ \\
El Palmar & 336.54 & $508.10(6.44)$ & $7,256.30(91.97)$ & $90.80(1.15)$ & $29.50(0.37)$ & $4.80(0.06)$ \\
\hline
\end{tabular}

$a$ : includes lagoons, rivers, swamps and streams; $b$ : vegetation without apparent human intervention, continuous canopy (> 70\%) and trees mean altitude of $18-30 \mathrm{~m} ; c$ : abandoned agricultural area in late succession state ( $>5$ years), coverage less than $50 \%$ and tree altitude over $5 \mathrm{~m}$; $d$ : abandoned agricultural area characterised by an early succession ( $<5$ years), median to scanty coverage, dominant life forms are grasses, bushes and small trees altitudes between 3-5 m; e: conuco, rock, bare soil or with very small vegetation coverage and vegetation associated with subsistence agriculture (annual crops such as cassava, plantains and yam).

\section{TABLE II}

Anopheline species collected on human landing catches (HLC), 48 all night collections with Mosquito Magnet ${ }^{\circledR}$ (MMLP) and CDC light traps in three study villages, state of Bolívar, Venezuela

\begin{tabular}{lcccccccc}
\hline & \multicolumn{2}{c}{ Jabillal } & El Palmar & & Surapire & \\
\hline Species & HLC $^{a}$ & MMLP & CDC & MMLP & CDC & MMLP & CDC & Total \\
\hline An. (Nys.) darlingi & 664 & 458 & 30 & 14 & 4 & 0 & 13 & 1,183 \\
An. (Nys.) nuneztovari s.1. & 439 & 520 & 7 & 3 & 0 & 3 & 0 & 972 \\
An. (Nys.) albitarsis s.1. & 140 & 22 & 0 & 0 & 0 & 0 & 0 & 162 \\
An. (Nys.) oswaldoi s.1. & 16 & 62 & 1 & 6 & 1 & 6 & 0 & 92 \\
An. (Nys.) braziliensis & 5 & 0 & 0 & 46 & 308 & 0 & 0 & 59 \\
An. (Nys.) strodei s.1. & 0 & 2 & 0 & 0 & 0 & 0 & 0 & 2 \\
An. (NYs.) triannulatus s.1. & 3 & 22 & 0 & 0 & 0 & 26 & 0 & 51 \\
An. (Nys.) argyritarsis & 0 & 1 & 1 & 1 & 0 & 0 & 0 & 3 \\
An. (Ano.) apicimacula & 0 & 0 & 1 & 0 & 0 & 0 & 0 & 1 \\
An. (Ano.) mediopunctatus & 1 & 0 & 0 & 0 & 0 & 0 & 0 & 1 \\
An. (Ano.) punctimacula & 0 & 1 & 0 & 1 & 0 & 0 & 0 & 2 \\
Not identifiable & 35 & 92 & 5 & 1 & 0 & 0 & 2 \\
\hline Total & 1,303 & 1,180 & 45 & 72 & 313 & 35 & 15 & 2,963 \\
\hline
\end{tabular}

$a$ : HLC carried out from 05:30 pm-09:30 pm between June 2008-January 2009 (number of nights $=16$ ); $b$ : due to loss of taxonomic characters.

$=0.179, \mathrm{P}=0.52)$. The CDC light trap was inefficient for sampling anophelines in this area, where abundance is low in general, although the light trap caught large numbers of Anopheles braziliensis (Chagas) in El Palmar. However, this occurrence only took place during the three all-night catches in September 2008 (Table II). In general, anophelines are more abundant during September and November after the peak rainfall during July and August. An. darlingi is present year-round, with a peak in September, while An. nuneztovari s.l. appeared in May and its abundance peaked in November (Fig. 2).

Species diversity was highest (11 species) in Jabillal, while only six species were caught in El Palmar and four in Surapire (Table II). To compare the three villages in terms of species diversity, a non-parametric ANOSIM test (Clarke 1993) was conducted. Significant differences were found between Jabillal and Surapire $(\mathrm{p}=$ $0.0003)$ and between Jabillal and El Palmar $(p=0.0003)$, while no significant difference was observed between El Palmar and Surapire $(p=1.0)$. The SIMPER method showed that the overall dissimilarity between Jabillal and El Palmar was $97.68 \%$ and the species that were primarily responsible for the observed differences were $A n$. darlingi (54.63\%) and An. nuneztovari s.1. (27.05\%); both species represented $81.68 \%$ of the observed dissimilarity. Although large numbers of An. braziliensis were 
caught $(91.9 \%)$ in El Palmar, this species only contributed $7.78 \%$ to the observed dissimilarity. The SIMPER between Jabillal and Surapire showed an overall dissimilarity of $96.49 \%$ and again, An. darlingi (59.09\%) and An. nuneztovari s.l. (29.14\%) were responsible for the observed significant differences, representing $88.23 \%$ of the resulting dissimilarity.

Biting activity - Based on hourly MMLP catches in Jabillal, An. darlingi was active throughout the night, with a peak at sunset and then a decrease in activity, while An. nuneztovari s.l. was more active at sunset, with a peak at 06:00 pm and a second minor peak at sunrise (Fig. 3). In general, in this area, the risk of contracting malaria is higher before 10:00 pm, when vectors are more active and individuals are unprotected outdoors.

Parity - An. darlingi showed a higher parous rate (66.7\%) in March (dry season) and then decreased until July, when it increased again, although only by less than $50 \%$. For An. nuneztovari, the parous rate increased gradually, reaching the maximum (45.5\%) in January (transition from wet to dry season) (Fig. 4).

Human-biting rate - To estimate the mean biting rate of the most abundant species, An. darlingi and An. nuneztovari s.l., in each village, all trapping methods were taken into account and the appropriate converting factor based on method and anopheline species was used (Table III). The mean biting rate was 38.21 bites/person/ night [standard deviation (SD) \pm 54.89 ] for An. darlingi and $25.39 \mathrm{bites} / \mathrm{person} / \mathrm{night}(\mathrm{SD} \pm 43.32$ ) for An. nuneztovari s.l. in Jabillal; this finding suggests that an individual might receive 13,947 bites/year from An. darlingi and 9,267 bites/year from An. nuneztovari s.l. When the overall risk for all species and methods was considered, the risk was much higher in Jabillal (33,277 bites/person/ year) compared with that in El Palmar (3,584 bites/person/year/) and Surapire (427 bites/person/year).

A Pearson correlation analysis between the mean biting rate and vegetation types showed that the mean biting rate was significantly higher in Jabillal, where there is higher coverage by secondary vegetation and bare soil-subsistence agriculture $(\mathrm{p}=0.03)$. In more forested

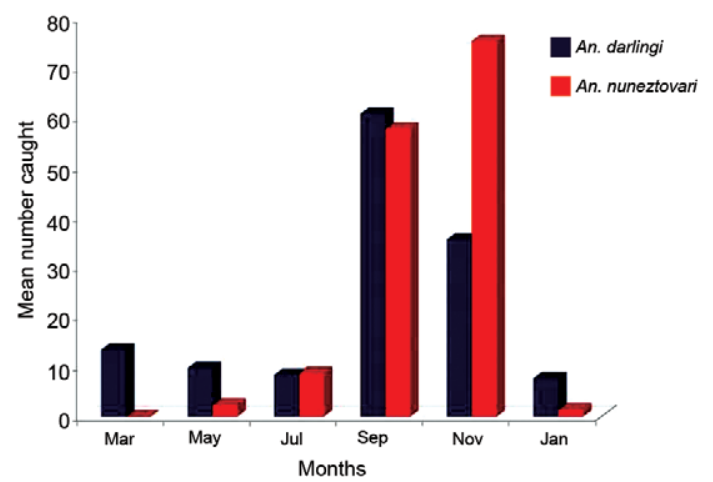

Fig. 2: mean number of Anopheles darlingi and Anopheles nuneztovari caught in Mosquito Magnet ${ }^{\circledR}$ traps in the study area between March 2008-January 2009, state of Bolívar, Venezuela. areas such as Surapire and El Palmar, the mean biting rate is lower. The biting rate is apparently not associated with the extent of coverage by water bodies, which are considered to be potential larval habitats $(\mathrm{p}=0.489)$.

Sporozoite rate and EIR - A total of 2,707 mosquitoes (313 pools) were assayed by ELISA: 1,118 An. darlingi, 877 An. nuneztovari, 354 An. braziliensis, 50 Anopheles oswaldoi (Peryassú), 50 Anopheles triannulatus (Neiva $\&$ Pinto) and 96 specimens that were unidentifiable due to loss of taxonomic characters. Two pools of An. darlingi were positive for $P$. vivax CS protein (Table IV). One pool from Jabillal was positive for $P$. vivax-247 and the other positive pool from El Palmar was positive for P. vivax-210. The sporozoite rate was higher in El Pal$\operatorname{mar}(7.14 \%)$, although this rate was not significantly different from that in Jabillal $(0.092 \%)$ due to the overlap of the $95 \%$ confidence intervals (CI) based on the binomial distributions of these rates (Drakeley et al. 2003) (Table IV). The overall sporozoite rate for An. darlingi was $0.179 \%$ (95\% CI, -0.07-0.43). The EIR, or mean humanbiting rate $\mathrm{x}$ sporozoite rate $\mathrm{x} 365$ days, was higher in El Palmar (20.85 infective bites/person/year) compared with Jabillal (12.55 bites/person/year). The overall EIR was 9.81 infective bites/person/year.

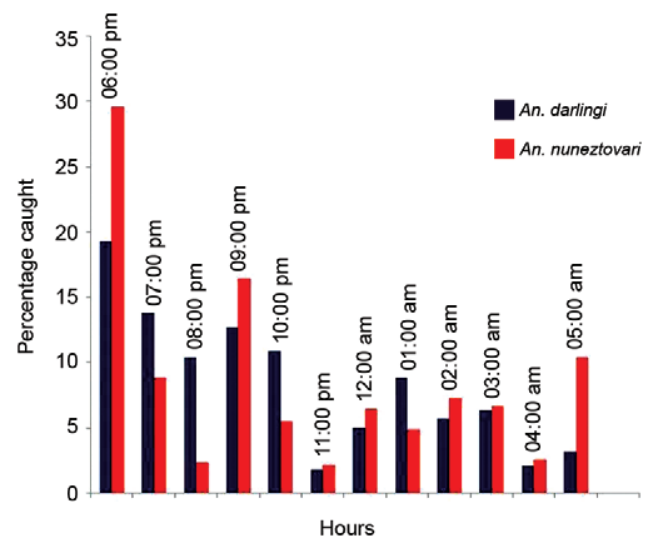

Fig. 3: biting cycle of Anopheles darlingi and Anopheles nuneztovari, state of Bolívar, Venezuela.

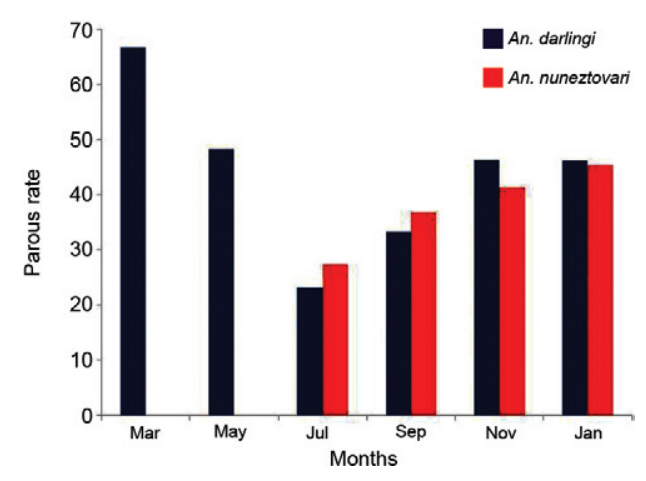

Fig. 4: parous rate of Anopheles darlingi and Anopheles nuneztovari between March 2008-January 2009 caught in Jabillal, municipality of Sucre, state of Bolívar, Venezuela. 


\section{DISCUSSION}

A surprising lack of primary research has been conducted on the effects of deforestation and changes in types of vegetation cover in relation to malaria transmission in Latin America, which is in contrast with the magnitude of the problem, as the estimated mean annual rate of deforestation is $0.33-0.51 \%$ and over 12 million people living in forested areas are at risk (Guerra et al. 2006, FAO 2010). The highest risk of malaria transmission is present in countries belonging to the Amazon Basin, which account for over $80 \%$ of the cases reported in the Americas (PAHO 2008).

The present study attempted to explore the effects of deforestation on entomological malaria risk factors at a small scale. Deforestation for slash-and-burn agriculture resulted in different degrees of vegetation succession in a radius of $5 \mathrm{~km}$ around the selected villages, which locally affected entomological parameters and thus the risk of malaria transmission.

Analysis of Landsat images has shown that 23,700 hectares were deforested in the Lower Caura River Basin between 1975-2005 at a rate of approximately 1,500 ha/year (Bevilacqua et al. 2006). The amount of deforestation around villages might be related to the history of the village itself. Jabillal was initially established over 100 years ago for the exploitation of tonka beans (seeds of Dipteryx odorata - sarrapia -, which contain a highly fragrant chemical compound used in the perfume industry), incipient cattle ranching and, currently, small-scale agriculture production. Surapire was established 30 years ago as a tourist camp and became a Ye'kwana set-

\section{TABLE III}

Mean daily biting rate for the most abundant species collected in three localitiesof the Lower Caura River Basin, municipality of Sucre, state of Bolívar, Venezuela

\begin{tabular}{lccc}
\hline Locality & $\begin{array}{c}\text { Anopheles } \\
\text { darlingi }\end{array}$ & $\begin{array}{c}\text { Anopheles } \\
\text { nuneztovari s.l. }\end{array}$ & Total $^{a}$ \\
\hline Jabillal & & & \\
mean & 38.21 & 25.39 & 91.17 \\
SD & 54.89 & 43.32 & 116.77 \\
95\% CI & 14.13 & 11.1 & 30.05 \\
El Palmar & & & \\
mean & 0.85 & 0.06 & 9.82 \\
SD & 5.28 & 0.55 & 43.32 \\
95\% CI & 1.19 & 0.01 & 11.1 \\
Surapire & & & \\
mean & 0.32 & 0.06 & 1.17 \\
SD & 1.69 & 0.55 & 3.43 \\
95\% CI & 0.41 & 0.01 & 0.83 \\
Overall & & & \\
mean & 11.56 & 7.42 & 30.66 \\
SD & 34.24 & 25.95 & 77.15 \\
95\% CI & 4.76 & 3.61 & 10.72 \\
\hline
\end{tabular}

$a$ : total includes all species collected; CI: confidence interval; SD: standard deviation. tlement approximately 15 years ago, while the more forested village of El Palmar was a new Sanema settlement $(<5$ years) at the time that this research commenced.

Yasuoka and Levins (2007) demonstrated that the impact of deforestation on mosquito density and malaria incidence is influenced by the nature of the agricultural development and ecological characteristics of local vector mosquitoes. In the present study, the Kruskal-Wallis test showed no correlation between higher cover by secondary vegetation/subsistence agriculture and the API, likely due to the small sample size. Furthermore, the least (Jabillal) and most (El Palmar) forested villages reported similar APIs (Table I). It is possible that an in-depth study of the entire Caura Basin, including the vegetation cover around 52 villages and the API, might coincide with the results reported by Yasuoka and Levins (2007).

The relative abundance and diversity of species were significantly higher in Jabillal, the village with the highest percentage of secondary vegetation and subsistence agriculture. A similar situation was reported by Tadei and Dutary Thatcher (2000) in Brazil, where the number of species in natural areas was smaller and An. darlingi was not present compared with areas altered by the construction of hydroelectric dams, oil pipelines, highways and towns where rapid and uncontrolled growth had occurred. Deforestation introduces environmental heterogeneity, resulting in more niches that can be colonised by different anopheline species. This phenomenon is the case for An. albitarsis s.l., a species that was absent from the more forested villages of El Palmar and Surapire, but was the third most abundant species collected in Jabillal. An. albitarsis s.l. can become an important malaria vector in altered areas, such as gold mining camps in Bolívar (Moreno et al. 2009). An interesting incongruity was the presence of relatively large numbers of An. braziliensis adult females caught in traps (CDC and MMLP) in El Palmar during the three night catches in September 2008, despite the fact that their larval habitats were not found in regular searches in a $5 \mathrm{~km}$ radius around the village (Rubio-Palis et al. unpublished observations). In terms of the abundance of An. darlingi, our results contrasted with those reported by Moutinho et al. (2011) for rural settlements in the state of Acre, Brazil, where abundance was higher in the most recent occupations closer to undisturbed forest.

Currently, 42 species of anophelines have been reported for Venezuela and 10 of these have been implicated in the transmission of malaria parasites (Rubio-Palis 2005). In the study area, as many as 11 species were collected and six of these species might be considered as potential malaria vectors: An. braziliensis, An. darlingi, An. albitarsis s.1., An. nuneztovari s.1., An. oswaldoi s.l. and An. triannulatus s.l. Only An. darlingi and An. nuneztovari $\mathrm{s}$.l. were sufficiently abundant to represent a risk and the An. nuneztovari parous rate was less than $50 \%$, which suggests that among the potential vectors in this region, An. darlingi is the species with the highest vectorial capacity (Garrett-Jones 1964) in terms of its abundance, parity (especially during the dry season) and well-known susceptibility to support the sporogonic cycle of all three Plasmodium species (Deane 1986, Klein et al. 1991a, b, 
TABLE IV

Plasmodium vivax (Pv-247 and Pv-210) circum-sporozoite (CS) protein positive Anopheles darlingi, mean biting rate and entomological inoculation rate (EIR) in three villages, municipality of Sucre, state of Bolívar, Venezuela

\begin{tabular}{|c|c|c|c|c|c|c|}
\hline Village & $(\mathrm{n})^{a}$ & $\begin{array}{l}\text { Positive for } P \text {. vivax CS } \\
\text { (n) }\end{array}$ & $\begin{array}{c}\text { Sporozoite rate } \\
(\%)\end{array}$ & $95 \%$ CI & Biting rate & $\mathrm{EIR}^{b}$ \\
\hline Jabillal & 1,091 & 1 & 0.092 & $-0.09-0.28$ & 38.21 & 12.55 \\
\hline El Palmar & 14 & 1 & 7.14 & $-6.35-20.6$ & 0.85 & 20.85 \\
\hline Surapire & 13 & 0 & 0 & $0.00-0.05$ & 0.32 & 0 \\
\hline Overall & 1,118 & 2 & 0.179 & $-0.03-0.12$ & 14.53 & 9.81 \\
\hline
\end{tabular}

$a$ : number of An. darlingi assayed by ELISA; $b$ : biting rate x sporozoite rate x 365 days; CI: confidence interval.

Magris et al. 2007b). In fact, An. darlingi was the only species found to be positive for $P$. vivax CS protein.

The biting cycle of $A n$. darlingi in this part of Venezuela showed an entirely different pattern from the biting patterns described in other parts of the country (Rubio-Palis 1995, Magris et al. 2007b, Moreno et al. 2007). The biting cycle of An. darlingi is known to vary along its range of distribution in the Americas, even between localities that are not far apart (Rubio-Palis 2000). In the present study, An. darling $i$ was active throughout the night, with $70 \%$ of bites occurring before midnight, but its abundance peaked at sunset and then decreased gradually until midnight, showing little fluctuation until sunrise. This pattern has not been previously described. An. nuneztovari s.l. was also active throughout the night, with an early biting peak at sunset, but also showed a second minor peak at sunrise. This behaviour is entirely different from the unimodal biting cycle reported for $A n$. nuneztovari in western Venezuela, with a peak between 10:00 pm-01:00 am (Rubio-Palis \& Curtis 1992). Nevertheless, longitudinal studies conducted in Suriname (Panday 1977, Rozendaal 1987) and Brazil (Consoli \& Lourenço-de-Oliveira 1994, Tadei \& Dutary Thatcher 2000, da Silva-Vasconcelos et al. 2002) reported a unimodal pattern with a biting peak at sunset. The observed pattern in our study area might be due to the presence of at least two species belonging to the nuneztovari complex. Currently, molecular studies of specimens collected in the study area are underway to clarify the taxonomy of potential malaria vectors, such as An. albitarsis s.l., An. nuneztovari s.l. and An. oswaldoi s.l.

In general, in this area, the risk of contracting malaria is higher before 10:00 pm, when vectors are more active and individuals are unprotected outdoors. This parameter is important to consider when planning and implementing vector control programs, especially those intended to interrupt transmission using insecticide-treated nets (ITNs). In this area, ITNs might not be as effective as in the Upper Orinoco River (Magris et al. 2007a), where An. darling $i$ is more active late in the evening when individuals are already in their hammocks (Magris et al. 2007b).

Regarding the human-biting rate, our analysis showed significantly higher $(\mathrm{p}=0.03)$ biting rates for An. darlingi (38.21 bites/person/night) and An. nuneztovari (25.39 bites/person/night) in Jabillal, the village with less forest, compared with the more forested villages of Surapire and El Palmar. A similar situation was reported by Vittor et al. (2006) for An. darlingi in the Peruvian Amazon, where deforestation is associated with road construction, although those authors reported much lower mean human-biting rates ranging from $6.5-0$ bites per person for An. darlingi and 0.3-0.1 for An. nuneztovari. It is interesting that previous studies conducted in Venezuela under different ecological conditions reported biting rates that were not only related to the degree of deforestation, but also potentially related to human activities. In fact, in the Upper Orinoco River (Amazonian Region), where deforestation around villages is associated with slash-and-burn agriculture, the mean human-biting rate for An. darlingi was found to be 46.06 bites/person/ night (Magris et al. 2007b), which is similar to the biting rate reported for Jabillal, while in the municipality of Sifontes, Bolívar (Guayana region), where deforestation of vast areas has occurred due to gold and diamond mining, the biting rate for An. darlingi was extremely low at 0.74 bites/person/night (Moreno et al. 2009). A contrasting situation might be observed in western Venezuela (savannah and forest vegetation in the Andean piedmont), where deforestation for subsistence agriculture and cattle ranching have resulted in very high biting rates for An. nuneztovari, especially during the rainy season (288 bites/person/night) (Rubio-Palis 1994).

The risk of contracting malaria in the study area was higher in El Palmar because it had the higher EIR; in a year, an individual might receive 20.85 infective bites or one infective bite every 17.4 days. No clear relationship was found between this parameter and deforestation and no correlation was observed between API and deforestation. However, these results confirm the findings of D Medina et al. (unpublished observations), who showed that the risk of contracting malaria in the Caura River Basin was $132 \%$ higher in individuals of the Sanema ethnic group with less than 10 years of residence in the area. In fact, when our studies began in El Palmar, which is inhabited by Amerindians of the Sanema ethnic group, the village was a recent colonisation of less than five years. These results are similar to those reported in the Brazilian states of Rondônia, (McGreevy et al. 1989, Castro et al. 2005) and Acre (Moutinho et al. 2011), where new settlements ( $<5$ years) closer to forests had significantly 
higher malaria prevalence rates than older established communities. No other study in the Neotropical region has correlated deforestation and EIRs, although Vittor et al. (2006) estimated the EIR to range from 0.1 bites/person/year in more forested areas to 38 bites/person/year in areas with more grass/crops (more deforestation) based on sporozoite rates for $A n$. darlingi previously reported in the Amazon Region and utilising a conservative rate of $0.5 \%$. Our results suggest that it is not appropriate to extrapolate these data because the impact of deforestation on malaria transmission is complex and varies locally (Guerra et al. 2006, Yasuoka \& Levins 2007).

\section{ACKNOWLEDGEMENTS}

To Alyne Filibert, Rodrigo Ramirez and Luis Manuel Pérez, for statistical analysis advise, to Ana Maria Ibañez, Horacio Vargas, Jabillal people, Dirección de Salud Ambiental del Estado Bolívar and technical staff and workers of Maripa Health Demarcation Post, for logistic support and friendship, to the Caura indigenous people Ye'kwana and Sanema, its community nurses, microscopists and youth counterpart, for entomological monitoring and epidemiological surveillance, to the Indigenous Organization of the Caura Kuyujani, by endorsement and support of the project, to Robert A Wirtz, Entomology Branch, CDC-Atlanta, for support in conducting the ELISAs, to ACOANA's technical and administrative team, to the team of IDRC, it's funding, contributions and valuable discussions on ecohealth approach for this project, and to the anonymous reviewers, for their critics and recommendations.

\section{REFERENCES}

Afrane YA, Lawson BW, Githeko AK, Yan G 2005. Effects of microclimatic changes due and land cover on the duration of gonotrophic cycles of Anopheles gambiae Giles (Diptera: Culicidae) in western Kenya highlands. J Med Entomol 42: 974-980.

Afrane YA, Little TJ, Lawson BW, Githeco AK, Gulyun Y 2008. Deforestation and vectorial capacity of Anopheles gambiae Giles mosquitoes in malaria transmission, Kenya. Emerg Infect Dis 14: 1533-1538.

Bevilacqua M, Medina D, Cárdenas L 2006. Situación de los Bosques de la Guayana, Venezuela. La cuenca del río Caura como caso de estudio. Available from: acoana.org/serie.html.

Bevilacqua M, Medina DA, Cárdenas L, Rubio-Palis Y, Moreno JE, Martinez A, all the community health workers of the Caura 2009. Orientaciones para fortalecer el programa de malaria en zonas remotas con población indígena en el Caura, Venezuela. Bol Malariol Salud Ambient 49: 53-71.

Castro MC, Monte-Mór RL, Sawyer DO, Singer BH 2005. Malaria risk on the Amazon frontier. Proc Natl Acad Sci USA 103: 2452-2457.

Clarke KR 1993. Non-parametric multivariate analysis of changes in community structure. Austral Ecol 18: 117-143.

Consoli RAGB, Lourenço-de-Oliveira R 1994. Principais mosquitos de importância sanitária no Brasil, Fiocruz, Rio de Janeiro, 225 pp.

Cova Garcia P, Sutil E 1977. Claves gráficas para la clasificación de anofelinos de Venezuela, División de Endemias Rurales/Dirección de Malariología y Saneamiento Ambiental, Maracay, 65 pp.

da Silva-Vasconcelos A, Kató MYN, Mourão EN, de Souza RTL, Lacerda RNL, Sibajev A, Tsouris P, Póvoa MM, Momen H, RosaFreitas MG 2002. Biting indices, host-seeking activity and natural infection rates of anopheline species in Boa Vista, Roraima, Brazil from 1996 to 1998. Mem Inst Oswaldo Cruz 97: 151-161.
Deane LM 1986. Malaria vectors in Brazil. Mem Inst Oswaldo Cruz 81 (Suppl. II): 5-14.

Detinova TS 1962. Age grouping methods in Diptera of medical importance with special reference to some vectors of malaria, WHO, Geneva, 216 pp.

Drakeley C, Schellenberg D, Kihonda J, Sousa CA, Arez AP, Lopes D, Lines J, Mshinda H, Lengeler C, Aemstrong Schellenberg A, Tanner M, Alonso P 2003. An estimation of the entomological inoculation rate for Ifakara: a semi-urban area in a region of intense malaria transmission in Tanzania. Trop Med Int Health 8: 767-774.

Eastman JR 2009. IDRISI Taiga. Guide to GIS and image processing, Clark Labs/Clark University, Worcester, 325 pp.

FAO - Food and Agriculture Organization of the United Nations 2010. Global forest resources assessment 2010 - main report, FAO, Rome, 378 pp.

Faran ME, Linthicum KJ 1981. A handbook of the Amazonian species of Anopheles (Nyssorhynchus) (Diptera: Culicidae). Mosq Syst 13: 1-81.

Garrett-Jones C 1964. Prognosis for the interruption of malaria transmission through assessment of the mosquito's vectorial capacity. Nature 204: 1173-1175.

Guerra CA, Snow RW, Hay SI 2006. A global assessment of closed forests, deforestation and malaria risk. Ann Trop Med Parasitol 100: $189-204$.

Guevara JM 2005. Meteorología. Colección Estudios, Consejo de Desarrollo Científico y Humanístico/Universidad Central de Venezuela, Caracas, 376 pp.

Hammer Ø, Harper DAT, Ryan PD 2001. PAST: Paleontological Statistics Software Package for Education and Data Analysis. Paleontol Electron 4: 9.

ISP - Instituto de Salud Pública 2008. Boletín regional. Dirección Regional de Salud Ambiental y Contraloría Sanitaria. Reporte Epidemiológico de la División Epidemiológica Sanitaria Ambiental. Semana 52. Available from: isp.gov.ve/salud.

Klein TA, Lima JBP, Tada MS 1991a. Comparative susceptibility of anopheline mosquitoes to Plasmodium falciparum in Rondônia, Brazil. Am J Trop Med Hyg 44: 598-603.

Klein TA, Lima JBP, Tada MS, Miller R 1991b. Comparative susceptibility of anopheline mosquitoes in Rondônia, Brazil, to infection by Plasmodium vivax. Am J Trop Med Hyg 45: 463-470.

Magris M, Rubio-Palis Y, Alexander N, Ruíz B, Galván N, Frías D, Blanco M, Lines J 2007a. Community-randomized trial and lambdacyhalothrin-treated hammock nets for malaria control in Yanomami communities in the Amazon Region of Venezuela. Trop Med Int Health 12: 1-12.

Magris M, Rubio-Palis Y, Menares C, Villegas L 2007b. Vector bionomics and malaria transmission in the Upper Orinoco River, southern Venezuela. Mem Inst Oswaldo Cruz 102: 303-312.

Martens P 1998. Health and climate change: modeling the impacts of global warming and ozone depletion, Earthscan Publications, London, $176 \mathrm{pp}$.

McGreevy PB, Dietze R, Prata A, Hembree SC 1989. Effects of immigration on the prevalence of malaria in rural areas of the Amazon Basin of Brazil. Mem Inst Oswaldo Cruz 84: 485-491.

Medina D, Bevilacqua M, Cárdenas L, Morales LG, Rubio-Palis Y, Martínez A, Behm V, Moreno J, Magris M 2011. Mapa de riesgo de transmisión de malaria en la cuenca del río Caura, Venezuela. Bol Malariol San Amb 51: 129-144.

Molyneaux DH 1998. Vector-borne parasitic diseases - an overview of recent changes. Int J Parasitol 28: 927-934. 
Molyneaux DH 2003. Common themes in changing vector-borne disease scenarios. Trans R Soc Trop Med Hyg 97: 129-132.

Moreno J, Rubio-Palis Y, Pérez E, Sánchez V, Páez E 2002. Evaluación de tres métodos de captura de anofelinos en un área endémica de malaria del estado Bolívar, Venezuela. Entomotropica 17: 157-165.

Moreno JE, Rubio-Palis Y, Páez E, Pérez E, Sánchez V 2007. Abundance, biting behavior and parous rate of anopheline mosquito species in relation to malaria incidence in gold-mining areas of southern Venezuela. Med Vet Entomol 21: 339-349.

Moreno JE, Rubio-Palis Y, Páez E, Pérez E, Sánchez V, Vaccari E 2009. Malaria entomological inoculation rates in gold mining areas of southern Venezuela. Mem Inst Oswaldo Cruz 104: 764-768.

Moutinho PR, Soares Gil LH, Bastos Cruz R, Martins Ribolla PE 2011. Populations dynamics, structure and behavior of Anopheles darlingi in a rural settlement in the Amazon rainforest of Acre, Brazil. Malar J 10: 174.

MPPS - Ministerio del Poder Popular para la Salud 2011. Boletín Integral de Salud Ambiental. Dirección General de Salud Ambiental. Semana 52. Available from: mpps.gob.ve/index.php?option=com content $\&$ view $=$ article \&id=927\&Itemid=915\&limitstart $=1$.

Olson SH, Gangnon R, Silveira GA, Patz JA 2010. Deforestation and malaria in Mâncio Lima county, Brazil. Emerg Infect Dis 16: $1108-1115$.

PAHO - Pan American Health Organization 2008. Malaria in the Americas: time series epidemiological data from 2000 to 2007. Available from: paho.org/English/AD/DPC/CD/mal-reg-country-epi-data-2007.pdf.

Panday RS 1977. Anopheles nuneztovari and malaria transmission in Suriname. Mosq News 37: 728-737.

Pattanayak SK, Yasuoka J 2008. Deforestation and malaria: revisiting the human ecology perspective. In CJP Colfer (ed.), People, health and forests: a global interdisciplinary overview, Earthscan Publications, London, p. 197-217.

Patz JA, Campbell-Lendrum D, Holloway T, Foley JA 2005. Impact of regional climate change on human health. Nature 438: 310-317.

Rozendaal JA 1987. Observations on the biology and behavior of anophelines in the Suriname rainforest with special reference to Anopheles darlingi Root. Cah ORSTOhf sér Ent méd et Pamsitd 25: 33-43.

Rubio-Palis Y 1994. Variation of the vectorial capacity of some anophelines in western Venezuela. Am J Trop Med Hyg 50: 420-424.

Rubio-Palis Y 1995. Observaciones sobre el patrón de actividad hematológica del vector de la malaria Anopheles darlingi en las poblaciones del sur de Venezuela. Bol Dir Malariol San Amb 35: 66-70.

Rubio-Palis Y 2000. Anopheles (Nyssorhynchus) de Venezuela: taxonomia, bionomía, ecologia e importáncia médica, Escuela de Malariología y Saneamiento Ambiental Dr Arnoldo Gabaldon/ Proyecto Control de Enfermedades Endémicas, Maracay, 120 pp.

Rubio-Palis Y 2005. Situación actual de la taxonomía de la subfamilia Anophelinae (Diptera: Culicidae) de Venezuela. Bol Mal Salud Amb 45: 1-10.

Rubio-Palis Y, Curtis CF 1992. Biting and resting behavior of anophelines in western Venezuela and implications for control of malaria transmission. Med Vet Entomol 6: 325-334.

Rubio-Palis Y, Moreno JE, Bevilacqua M, Medina D, Martínez A, Cárdenas L, Guzmán H, González J 2010. Caracterización ecológica de los anofelinos y otros culícidos en territorio indígena del Bajo Caura, estado Bolívar, Venezuela. Bol Mal Salud Amb 50: 95-107.

Rubio-Palis Y, Moreno JE, Sánchez V, Estrada Y, Anaya W, Bevilacqua M, Cárdenas L, Martínez A, Medina D 2012. Can Mosquito Magnet ${ }^{\mathbb{R}}$ substitute for human-landing catches to sample anopheline populations? Mem Inst Oswaldo Cruz 107: 546-549.

Tadei WP, Dutary Thatcher B 2000. Malaria vectors in the Brazilian Amazon: Anopheles of the subgenus Nyssorhynchus. Rev Inst Med Trop Sao Paulo 42: 87-94.

Vargas H, Rangel J 1996. Clima: comportamiento de las variables. Scientia Guaianae 6: 34-39.

Vittor AY, Gilman RH, Tielsch J, Glass G, Shields T, Sánchez Lozano W, Pinedo-Cancino V, Patz JA 2006. The effect of deforestation on the human-biting rate of Anopheles darlingi, the primary vector of falciparum malaria in the Peruvian Amazon. Am J Trop Med Hyg 74: 3-11.

Walsh JF, Molyneaux DH, Birley MH 1993. Deforestation: effects on vector-borne disease. Parasitology 106: S55-S75.

WHO - World Health Organization 1975. Manual on practical entomology, Parts I and II, WHO, Geneva, 191 pp.

Wirtz RA, Burkot TR, Graves PM, Andre RG 1987. Field evaluation of enzyme-linked immunosorbent assays for Plasmodium falciparum and Plasmodium vivax sporozoites in mosquitoes (Diptera: Culicidae) from Papua New Guinea. J Med Entomol 24: 433-437.

Wirtz RA, Sattabongkot J, Hall T, Burkot TR, Rosenberg R 1992. Development and evaluation of an ELISA for Plasmodium vivaxVK247 sporozoites. J Med Entomol 29: 854-857.

Yasuoka J, Levins R 2007. Impact of deforestation and agricultural development on anopheline ecology and malaria epidemiology. Am J Trop Med Hyg 76: 450-460. 